\title{
Consumer-Oriented Sales Promotion of Organic Food in Slovakia and the Czech Republic
}

\author{
Paulína Krnáčová1 - Martin Závodský²
}

\begin{abstract}
Based on the evaluation of partial research results the aim of the presented paper is to find out current state of using consumer-oriented sales promotion tools at the organic food market in Slovakia and the Czech Republic and to suggest recommendations for improvement. We conducted primary quantitative research by inquiry method via standardized online questionnaire. The research results reveal that the most used consumeroriented sales promotion tools are information materials, merchandising and multipacks. Business entities focus on the non-monetary sales promotion. The results point to insufficient implementation of sales promotion tools at the organic food market and probably low interest of business entities to them.
\end{abstract}

\section{Key words}

organic food, sales promotion, consumer-oriented sales promotion

\section{J EL Classification: M31}

Received: 29.5.2018 Accepted: 26.10.2018

\section{I ntroduction}

The organic food market is expanding worldwide annually. In the last decades, it has resulted in multi discipline of the research focused on the psychological and anthropological factors of organic food consumption. Several studies concluded that ethical principles, such as ecological sustainability and care for animal welfare influence the consumer choices of organic food. Other studies claim that consumers of organic food are motivated by the perceived healthiness of such products (Guido, 2009; Guido et al., 2010; Siegrist, 2008; Pino et al., 2012). Since consumer attitudes have an essential role on the success of sales promotion activities, the business entities should pay attention to identification of consumer segments and implementation of customized strategies. Furthermore, the increased availability of information about consumers' behavior enables and simplifies to customize marketing efforts to the consumer preferences (Venkatesan and Farris, 2012a).

Based on the results of studies (Mela et al., 1997; Papatla and Krishnamurthi, 1996), sales promotions have a significant impact on the consumer's decision making process. Approximately $70 \%$ of decisions about which brand to purchase are made instore (De Pelsmacker et al., 2001). Therefore, business entities want to understand and

1 Ing. Paulína Krnáčová, PhD., Department of Commodity Science and Product Quality, Faculty of Commerce, University of Economics in Bratislava, Dolnozemská cesta 1, 85235 Bratislava, Slovakia, paulina.krnacova@euba.sk

2 Ing. Martin Závodský, ALAMEX s. r. o., Popolná 10, 83106 Bratislava, Slovakia, martin@alamex.sk 
influence this decision process. Understanding the factors that influence an existing or potential customer's decision process is essential for business entities in implementation of an effective marketing mix that generates sales. Besides product characteristics and price, promotional activities are the most popular tools used by manufacturers and retailers to influence the consumer's decision process (Nagar, 2009).

Sales promotion can be defined as marketing activities usually specific to a time period, place or customer segment, which encourage a direct response from consumer or marketers, through the offer of additional benefits. Sales promotion has been labeled almost exclusively as short-term and tactical instruments. The nature and duration of the effects of sales promotion is still a topic of contention among marketing practitioners. The incremental, and usually temporary, effect of sales promotion on sales seems to be widely accepted, while the profitability of sales promotion is a more contentious issue. There is also evidence that increased promotional activity weakens brand loyalty, detracts brand quality image, and generates a short-term management orientation. The fundamental features of sales promotion can be summarized as follows (Brito and Hammond, 2007):

- Incentive or inducement to generate immediate sales boost;

- Effects are short rather than long-term;

- Secondary and subordinate status or role when compared with advertising.

Sales promotions are being used not only at the business-to-customer (B2C) but also business-to-business (B2B) market. There are several various sales promotion classifications, such as „active, „passive, „price”, "non-price”, „value-increasing” or „valueadding" and "monetary" and "nonmonetary" sales promotions. Even if there have been different classifications, there are three main sales promotion categories as follow (Köksal and Spahiu, 2014): (1) consumer-oriented sales promotion (samples, coupons, cash refunds, cents-off deals, premiums, Point-Of-Purchase promotions); (2) trade-oriented sales promotion (discounts, allowance, free goods, advertising items, etc.); and (3) business- or retailer-oriented sales promotion (trade shows, sales contests, rewarding customers, motivating sale people).

Sales promotion has been collected to attract consumers' attention such as price and brand perception, brand choice, evaluation and equity, etc. (Srilekha and Jawahar, 2011). One of the purposes of a consumer-oriented sales promotion is to elicit a direct impact on the purchase behavior of the consumers. Sales promotion provide various advantages to retailers such as (1) accelerating sales, (2) increasing shelf space revenue, (3) encouraging and motivating sales representatives to interact with customers; and (4) producing increased tangible sales (Owens et al., 2001).

\section{Methodology}

Selection of scientific methods depends on the paper content focus and the paper aim. To elaborate theoretical knowledge, we primarily used theoretical scientific methods, including method of analysis and synthesis, method of induction and deduction, abstraction and concretization, but also the comparative method. As a method of collecting primary data we conducted research. We evaluated and interpreted the obtained 
quantitative data through statistical and graphical methods in the Statgraphics software and MS Excel.

Based on the research results the aim of the presented paper was to find out current state of using consumer-oriented sales promotion tools at the organic food market and to suggest recommendations for improvement.

The basis for the analysis of sales promotion of organic food represents the results of primary research that we conducted by the inquiry method through the standardized online questionnaire in February 2017. Our research was focused on two groups of respondents: (1) consumers and their attitude to sales promotion tools of organic food; and (2) business entities in the field of organic food. However, this paper is focused on the analysis of partial results concerning the attitude of producers and retailers of organic food to sales promotion. We set the following research questions:

Which tools of sales promotion do business entities in the field of organic food in Slovakia and the Czech Republic use?

What is the attitude of the producers and sellers of organic food in Slovakia and Czech Republic to the selected tools of sales promotion?

Based on the list of control authorities Naturalis SK and eAGRI (CZ), 100 Slovak and 100 Czech producers and retailers were selected randomly and contacted via an online questionnaire. After testing for complexity, accuracy, validity, reliability and consistency, we analyzed 43 questionnaires, representing a return of $21.5 \%$.

The questionnaire consisted of 12 closed-ended and open-ended questions. The respondent's answers were evaluated through frequency tables and cross tabulations, in some cases relevant descriptive statistics (e.g. average, standard deviation) were calculated.

\section{Results and Discussion}

\subsection{Consumer perception of organic food sale}

One of the most important factor of consumer's buying process of organic food is that consumers perceive their higher quality. Question of organic food quality has been subject of many scientific debates for a considerable amount of time. Numerous scientific studies have been carried out in the past that have addressed the issue of the quality of organic food as compared to conventionally produced foods. Various studies compared values such as dry matter content, sugar content or content of vitamin $C$ in organically and conventionally produced foods. There are many organic food adherents in the scientific world, but also their counterparts (Kahl et al., 2012).

According to a study carried out in 2009 that had summarized scientific articles and publications since 1958, organic food do not have higher nutritional value and higher quality (Dangour et al., 2009). 
The most recent study from the year 2014 claims that higher value of antioxidants, lower cadmium content and lower value of pesticide residues are found in organically grown foods (Barański et al., 2014).

The main factors influencing consumer decision-making when choosing and purchasing organic food can be described as follow (Dickieson and Arkus, 2009):

- Consciousness of health - consumers who purchase organic products take care about their health, promote and live a healthy lifestyle. Health can be mentioned as the most important factor associated with the very concept of organic food.

- Effort - the supply of organic food is demand-oriented, product range limited and not available everywhere. It depends on the efforts of the consumers, where they are willing to go to buy these foods.

- Consumer confidence - economic factors can greatly influence consumer-purchasing decisions. For example, in the case of an economic crisis, the consumer reconsider whether he is willing to spend more money on more expensive organic food when his/her own existence is threatened.

- Perception of quality - consumers associate the term "organic" with the higher quality that is also one of the reasons why consumers buy organic products. In the case of conventional products, price is the most considerable factor.

- Importance of social status - for some consumers, organic food and its higher prices are such as manifestation of their social status or lifestyle. Therefore, some consumers do not buy these products for protecting their health or promoting environmental protection, but as a way of expressing themselves, a fashion trend or a level that no one can afford.

- Premium prices - high prices are the most important factor that says "against" organic food compared to conventional products. On the one hand, higher price can act as barrier to the purchase of the organic food; on the other hand, the higher price is associated with a perceived higher quality.

- Confidence in labeling and marketing - when purchasing organic food, the consumer has to trust the producer that the food labeling is not misleading or deceptive and rely on the reliability of the declared certificates.

- Value - the consumer's decision to buy organic food is not only a result of his/her psyche but a reflection of his/her life values.

- Food safety concerns - concerns about the use of pesticides or genetically modified organisms represent an important reason why consumers buy organic food that they trust and consider as safe.

Hughner et al. (2007) divide the theories and barriers of organic food purchases into fifteen topics explaining consumers' attitudes towards organic food. The consumer choice and purchase of organic food are motivated by: (1) health and nutrition, (2) better taste, (3) environmental concern, (4) concern about food safety, (5) concern over animal welfare, (6) support of local economy, (7) higher beneficial effect, (8) nostalgia, and (9) fashionable and/or curiosity. In spite of many positive aspects that encourage consumers to buy organic food, there are also barriers that also affect consumer buying behavior: (1) high prices, (2) lack of availability, (3) skepticism and mistrust of labeling, (4) insufficient marketing, (5) satisfaction with the current food source; and (6) sensory defects. 
From the point of view of organic food retailers, marketing activities are mainly focused on presenting the different values associated with these products (Marketingschools.org, 2016):

- altruism (relationship to others),

- ecology (unity with the universe),

- universality (protecting the welfare of people and nature);

- charity (enriching the welfare of relatives),

- $\quad$ Spirituality (inner peace)

- Self-control (independent thinking and action).

Many companies build their image based on the low impact of their activities on the environment and on the local character of the products. By presenting their products as organic and at the same time the products of their competitors as potentially dangerous, they attract consumers who promote environmental protection and alternative lifestyles. When a consumer buy products that meet his/her values and lifestyle, he/she fulfill his/her egoistic needs that make him/her feel better (Marketing-schools.org, 2016).

At the organic food market, the concept of quality is very important because consumers expect a higher price and a higher quality of organic food compared to traditional/conventional food. The selling process of quality and certified organic food no longer ends by sales. Business in the organic food market is associated with the different groups of interested parties: customers are interested in products; scientists and experts pay attention to organic projects; potential (but also fake) retailers and farmers are interested in cooperation and, lastly, state authorities that primarily set legislative requirements, manage and control compliance with the set requirements (Elzakker \& Eyhorn, 2010).

The concept of organic food quality has been developing for decades and has gradually begun to push from a product-oriented concept of quality to a consumer-oriented concept. Every part of the food chain, from farmer to consumer, has its own requirements that change over time under the influence of social changes or scientific development. The quality of organic food can be assessed by six aspects (Kahl et al., 2010): (1) authenticity, (2) function and storage, (3) biology/physiology, (4) nutrition, (5) sensual perceptions; and (6) ethics.

\subsection{Consumer-oriented Sales Promotion tools Used at the Organic Food Market}

Based on the research results the aim of the presented paper is to find out current state in using consumer-oriented sales promotion tools as one part of the marketing communication tools at the organic food market.

In this part of the paper, we present partial results of the research that provide us with answers to the research questions and testify to using of sales promotion tools by organic food business entities.

A total of 43 representatives of business entities participated in the research, of which 25 (58\%) represented Slovakia and 18 (41\%) the Czech Republic (see graph 1). 
Graph 1 Structure of research sample

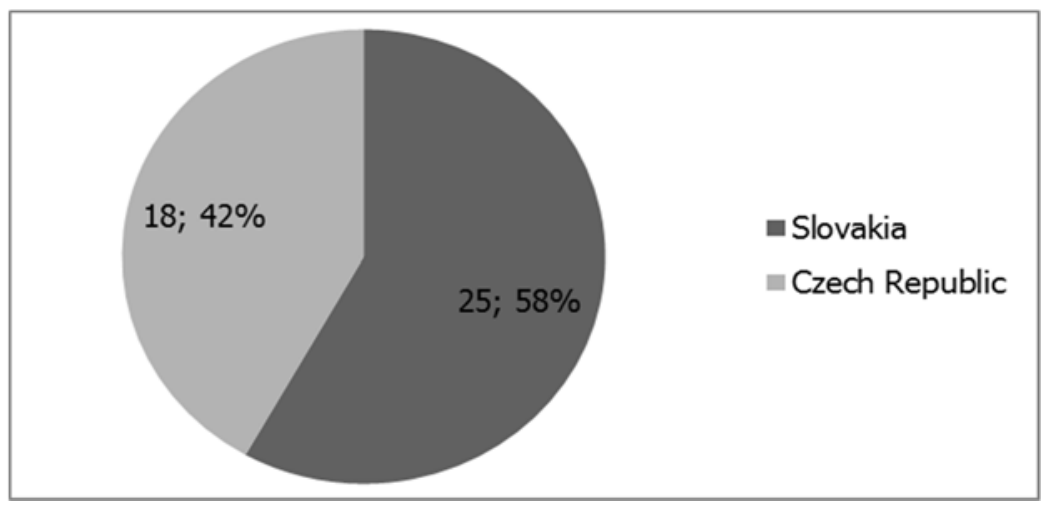

Source: own results

In terms of Slovak business entities structure, there was the largest representation of retailers (16, i.e. $64 \%)$ and companies dedicated to production and sale of organic food to wholesale and/or retailers and final consumers (6, i.e. $24 \%$ ). Companies engaged in production and sale to final consumers were represented by 3 business entities (i.e. $12 \%$ ).

In the case of Czech business entities, there was the largest representation of companies focused on production and sale to wholesale and/or retailers and to final consumers (10, i.e. $56 \%)$. Second largest group was represented by business entities that produce and sale organic food to wholesale and/or retailers (6, i.e. $33 \%)$.

Graph 2 Structure of business entities in Slovakia and the Czech Republic

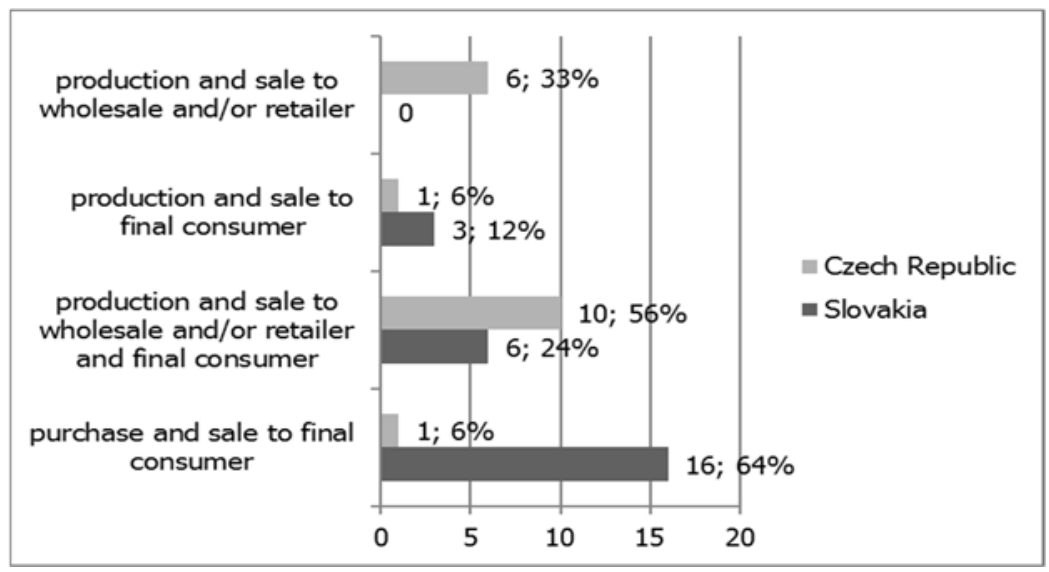

Source: own results

\section{Which tools of sales promotion do Slovak and Czech business entities use?}

Within the research, we wanted to find out which forms of consumer-oriented sales promotion do producers and sellers use. This part of research was dedicated to the business entities that offer organic food to final consumers, i.e. 25 Slovak and 12 Czech 
business entities. When evaluating the research, points were assigned to each option (1 - always; 6 - do not use) and based on the average assessment of individual aspects we determined their order of importance.

Tab. 1 Frequency of consumer-oriented sales promotion tools using in Slovakia and the Czech Republic

\begin{tabular}{|c|c|c|c|c|c|c|c|c|c|}
\hline $\begin{array}{l}\text { Consumer- } \\
\text { oriented } \\
\text { sales promo- } \\
\text { tion forms }\end{array}$ & & $\sum_{\frac{1}{4}}^{n}$ & 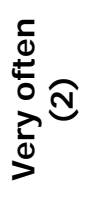 & $\stackrel{\frac{5}{d}}{\frac{m}{\delta}}$ & 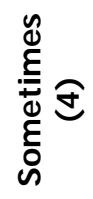 & 齐 & 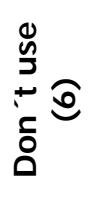 & 过 & $\frac{\text { o }}{\frac{2}{2}}$ \\
\hline \multirow{2}{*}{$\begin{array}{l}\text { Free samples } \\
\text { and tastings }\end{array}$} & SVK (25) & $\begin{array}{c}1 \\
4 \%\end{array}$ & $\begin{array}{c}5 \\
20 \%\end{array}$ & $\begin{array}{c}3 \\
12 \%\end{array}$ & $\begin{array}{c}8 \\
32 \%\end{array}$ & $\begin{array}{c}5 \\
20 \%\end{array}$ & $\begin{array}{c}3 \\
12 \%\end{array}$ & 3.80 & 2 \\
\hline & CZ (12) & $\begin{array}{c}2 \\
17 \% \\
\end{array}$ & $\begin{array}{c}1 \\
8 \% \\
\end{array}$ & $\begin{array}{c}0 \\
0 \% \\
\end{array}$ & $\begin{array}{c}5 \\
42 \% \\
\end{array}$ & $\begin{array}{c}3 \\
25 \% \\
\end{array}$ & $\begin{array}{c}1 \\
8 \% \\
\end{array}$ & 3.75 & 3 \\
\hline \multirow{2}{*}{$\begin{array}{l}\text { Discount cou- } \\
\text { pons }\end{array}$} & SVK (25) & $\begin{array}{c}2 \\
8 \% \\
\end{array}$ & $\begin{array}{c}2 \\
8 \% \\
\end{array}$ & $\begin{array}{c}1 \\
4 \% \\
\end{array}$ & $\begin{array}{c}8 \\
32 \% \\
\end{array}$ & $\begin{array}{c}4 \\
16 \% \\
\end{array}$ & $\begin{array}{c}8 \\
32 \% \\
\end{array}$ & 4.36 & 6 \\
\hline & CZ (12) & $\begin{array}{c}0 \\
0 \% \\
\end{array}$ & $\begin{array}{c}1 \\
8 \% \\
\end{array}$ & $\begin{array}{c}1 \\
8 \% \\
\end{array}$ & $\begin{array}{c}3 \\
25 \% \\
\end{array}$ & $\begin{array}{c}3 \\
25 \% \\
\end{array}$ & $\begin{array}{c}4 \\
33 \% \\
\end{array}$ & 4.67 & 5 \\
\hline \multirow{2}{*}{ Gift items } & SVK (25) & $\begin{array}{c}1 \\
4 \%\end{array}$ & $\begin{array}{c}1 \\
4 \%\end{array}$ & $\begin{array}{c}1 \\
4 \%\end{array}$ & $\begin{array}{c}13 \\
52 \%\end{array}$ & $\begin{array}{c}4 \\
16 \%\end{array}$ & $\begin{array}{c}5 \\
20 \%\end{array}$ & 4.32 & 5 \\
\hline & CZ (12) & $\begin{array}{c}0 \\
0 \% \\
\end{array}$ & $\begin{array}{c}0 \\
0 \% \\
\end{array}$ & $\begin{array}{c}0 \\
0 \% \\
\end{array}$ & $\begin{array}{c}4 \\
33 \% \\
\end{array}$ & $\begin{array}{c}2 \\
17 \% \\
\end{array}$ & $\begin{array}{c}6 \\
50 \% \\
\end{array}$ & 5.17 & 8 \\
\hline \multirow{2}{*}{$\begin{array}{l}\text { Loyalty pro- } \\
\text { grams }\end{array}$} & SVK (25) & $\begin{array}{c}3 \\
12 \% \\
\end{array}$ & $\begin{array}{c}2 \\
8 \% \\
\end{array}$ & $\begin{array}{c}2 \\
8 \%\end{array}$ & $\begin{array}{c}4 \\
16 \% \\
\end{array}$ & $\begin{array}{c}0 \\
0 \%\end{array}$ & $\begin{array}{c}14 \\
56 \%\end{array}$ & 4.52 & 7 \\
\hline & CZ (12) & $\begin{array}{c}1 \\
8 \%\end{array}$ & $\begin{array}{c}0 \\
0 \%\end{array}$ & $\begin{array}{c}0 \\
0 \%\end{array}$ & $\begin{array}{c}2 \\
17 \%\end{array}$ & $\begin{array}{c}0 \\
0 \%\end{array}$ & $\begin{array}{c}9 \\
75 \%\end{array}$ & 5.25 & 9 \\
\hline \multirow{2}{*}{$\begin{array}{l}\text { Games and } \\
\text { contests }\end{array}$} & SVK (25) & $\begin{array}{c}1 \\
4 \% \\
\end{array}$ & $\begin{array}{c}0 \\
0 \% \\
\end{array}$ & $\begin{array}{c}2 \\
8 \% \\
\end{array}$ & $\begin{array}{c}2 \\
8 \% \\
\end{array}$ & $\begin{array}{c}6 \\
24 \% \\
\end{array}$ & $\begin{array}{c}14 \\
56 \% \\
\end{array}$ & 5.16 & 8 \\
\hline & $C Z(12)$ & $\begin{array}{c}0 \\
0 \% \\
\end{array}$ & $\begin{array}{c}0 \\
0 \% \\
\end{array}$ & $\begin{array}{c}1 \\
8 \% \\
\end{array}$ & $\begin{array}{c}2 \\
17 \% \\
\end{array}$ & $\begin{array}{c}6 \\
50 \% \\
\end{array}$ & $\begin{array}{c}3 \\
25 \% \\
\end{array}$ & 4.92 & 6 \\
\hline \multirow{2}{*}{ Discounts } & SVK (25) & $\begin{array}{c}2 \\
8 \% \\
\end{array}$ & $\begin{array}{c}3 \\
12 \% \\
\end{array}$ & $\begin{array}{c}6 \\
24 \% \\
\end{array}$ & $\begin{array}{c}5 \\
20 \% \\
\end{array}$ & $\begin{array}{c}3 \\
12 \% \\
\end{array}$ & $\begin{array}{c}6 \\
24 \%\end{array}$ & 3.88 & 4 \\
\hline & CZ (12) & $\begin{array}{c}1 \\
8 \% \\
\end{array}$ & $\begin{array}{c}2 \\
17 \%\end{array}$ & $\begin{array}{c}2 \\
17 \%\end{array}$ & $\begin{array}{c}2 \\
17 \%\end{array}$ & $\begin{array}{c}1 \\
8 \%\end{array}$ & $\begin{array}{c}4 \\
33 \%\end{array}$ & 4.00 & 4 \\
\hline \multirow{2}{*}{$\begin{array}{l}\text { Merchandis- } \\
\text { ing }\end{array}$} & SVK (25) & $\begin{array}{c}5 \\
20 \% \\
\end{array}$ & $\begin{array}{c}4 \\
16 \% \\
\end{array}$ & $\begin{array}{c}4 \\
16 \% \\
\end{array}$ & $\begin{array}{c}1 \\
4 \% \\
\end{array}$ & $\begin{array}{c}0 \\
0 \% \\
\end{array}$ & $\begin{array}{c}11 \\
44 \% \\
\end{array}$ & 3.80 & 2 \\
\hline & CZ (12) & $\begin{array}{c}2 \\
17 \% \\
\end{array}$ & $\begin{array}{c}1 \\
8 \% \\
\end{array}$ & $\begin{array}{c}2 \\
17 \% \\
\end{array}$ & $\begin{array}{c}3 \\
25 \% \\
\end{array}$ & $\begin{array}{c}2 \\
17 \% \\
\end{array}$ & $\begin{array}{c}2 \\
17 \% \\
\end{array}$ & 3.67 & 2 \\
\hline \multirow{2}{*}{$\begin{array}{l}\text { I nformation } \\
\text { materials }\end{array}$} & SVK (25) & $\begin{array}{c}1 \\
4 \% \\
\end{array}$ & $\begin{array}{c}6 \\
24 \% \\
\end{array}$ & $\begin{array}{c}7 \\
28 \%\end{array}$ & $\begin{array}{c}6 \\
24 \% \\
\end{array}$ & $\begin{array}{c}2 \\
8 \% \\
\end{array}$ & $\begin{array}{c}3 \\
12 \% \\
\end{array}$ & 3.44 & 1 \\
\hline & CZ (12) & $\begin{array}{c}3 \\
25 \% \\
\end{array}$ & $\begin{array}{c}4 \\
33 \% \\
\end{array}$ & $\begin{array}{c}2 \\
17 \% \\
\end{array}$ & $\begin{array}{c}1 \\
8 \% \\
\end{array}$ & $\begin{array}{c}2 \\
17 \% \\
\end{array}$ & $\begin{array}{c}0 \\
0 \% \\
\end{array}$ & 2.58 & 1 \\
\hline \multirow{2}{*}{ Multipacks } & SVK (25) & $\begin{array}{c}2 \\
8 \% \\
\end{array}$ & $\begin{array}{c}2 \\
8 \% \\
\end{array}$ & $\begin{array}{c}7 \\
28 \% \\
\end{array}$ & $\begin{array}{c}6 \\
24 \% \\
\end{array}$ & $\begin{array}{c}3 \\
12 \% \\
\end{array}$ & $\begin{array}{c}5 \\
20 \% \\
\end{array}$ & 3.84 & 3 \\
\hline & CZ (12) & $\begin{array}{c}0 \\
0 \%\end{array}$ & $\begin{array}{c}0 \\
0 \%\end{array}$ & $\begin{array}{c}0 \\
0 \%\end{array}$ & $\begin{array}{c}3 \\
25 \%\end{array}$ & $\begin{array}{c}6 \\
50 \%\end{array}$ & $\begin{array}{c}3 \\
25 \%\end{array}$ & 5.00 & 7 \\
\hline
\end{tabular}

Source: own results 
Based on the results shown in table 1, we have found out that Slovak business entities prefer to use information/promotional materials provided in the stores/shops (1st position in ranking), merchandising and free samples and tastings (2nd position) and multipacks (3rd position).

The practices in the field of consumer-oriented sales promotion tools of Czech business entities are very similar to the Slovak ones. They use especially information materials (1st position), merchandising (2nd position) and free samplings and tastings (3rd position). The most significant difference compared to Slovak companies is the ranking position of multipacks, which ranks up to seventh position in the case of Czech companies.

What is the attitude of business entities in the field of organic food in Slovakia and Czech Republic to the tools of sales promotion?

Furthermore, we focused also on the attitude of business entities to claims that indirectly relate to using of consumer-oriented sales promotion tools. $44 \%$ of Slovak companies agree that discounted organic food are sold easier. The most majority of respondents (64\%) highlight/display new organic food at the point of purchase. Moreover, $52 \%$ of Slovak business entities believe that consumers have enough information on what they are buying. About a half of the companies (52\%) have opinion that consumers are interested in free samples and tasting of organic food. $56 \%$ of business entities agree that discount coupons enable to motivate consumers to buy organic food. The same amount of companies (56\%) agrees that consumers are loyal to one food organic brand.

Graph 3 Attitudes of the Slovak business entities

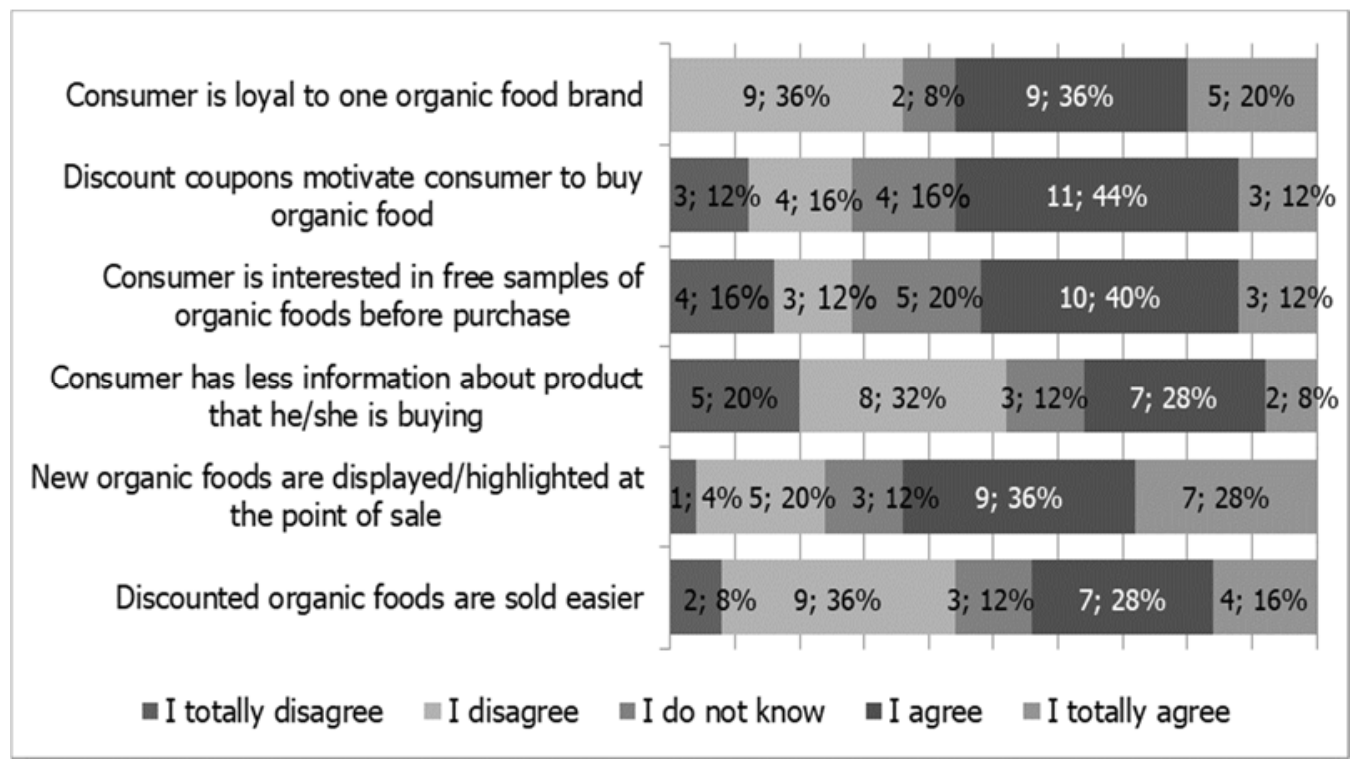


Comparing to Slovak business entities, similar number of Czechs (42\%) agree that discounted organic food are sold easier. The rest of Czech companies (84\%) highlight/display organic food at the point of sale. Based on results shown in graph 4 we assume that the most important sales promotion tools are discounted coupons (besides displaying products at the point of sale). $75 \%$ of business entities consider discount coupons as motivation factor for consumers but only $66 \%$ of business entities use this tool very often to rarely (see table 1 ). Regarding the loyalty of Czech consumer, exactly a half of the business entities agree that consumers are loyal to one organic food brand.

Graph 4 Attitudes of the Czech business entities

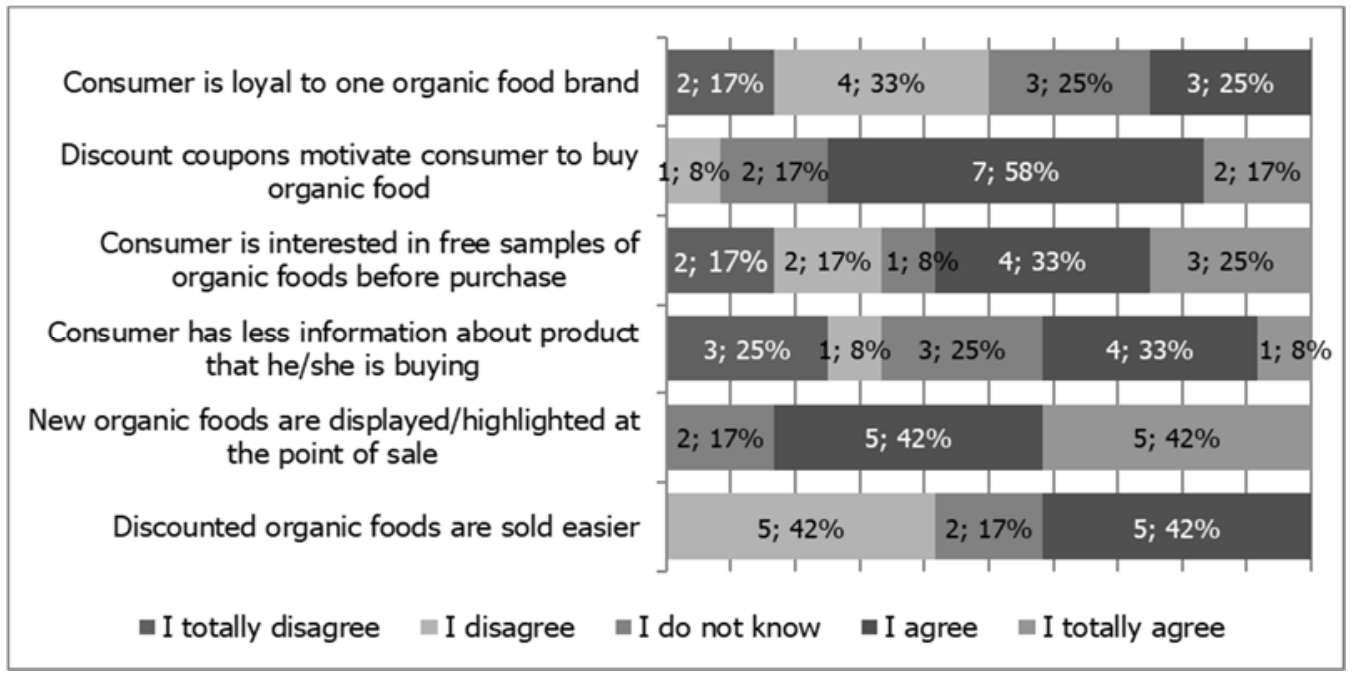

Source: own results

Why do business entities use selected consumer-oriented sales promotion tools? What is their motivation?

The aim of this part of research was to find out if the business entities know the benefits of sales promotion. At first, we wanted to know why they offer discounts for selected organic food.

As results in graph 5 show, the business entities in both countries consider increasing of sale as the most important benefit. $48 \%$ of the Slovak companies use discount with the aim to reduce stock surplus and $40 \%$ of them would like to attract new customers. On the other hand, $50 \%$ of Czech companies are focused on attracting new customers. 
Graph 5 Benefits of discounts from the business entities' point of view

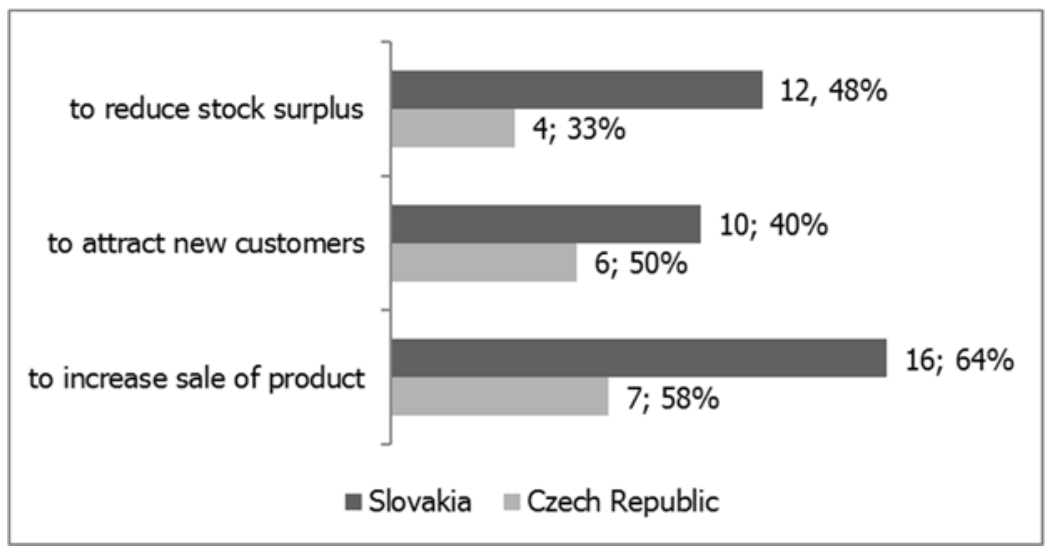

Source: own results

Regarding the reasons why the business entities use gift items for free as sales promotion tool, we found out that $68 \%$ of Slovak companies are oriented to build longterm relationships with their customers (see graph 6) or to stimulate repeat purchase $(36 \%)$. There is a psychology to sales and selling and reciprocity matters. Giving away free gifts and free samples is a prime example of reciprocity. Customer may not buy directly after receiving a free reward, but when they do become sales-ready, the likelihood is that they will remember their obligation to the company who gave them something. To be more open to the possibility of buying from them (Bain 2013). A half of the Czech business entities try to build long-term relationships with their customers by offering them gift items for free.

Graph 6 Reasons of using gift items for free

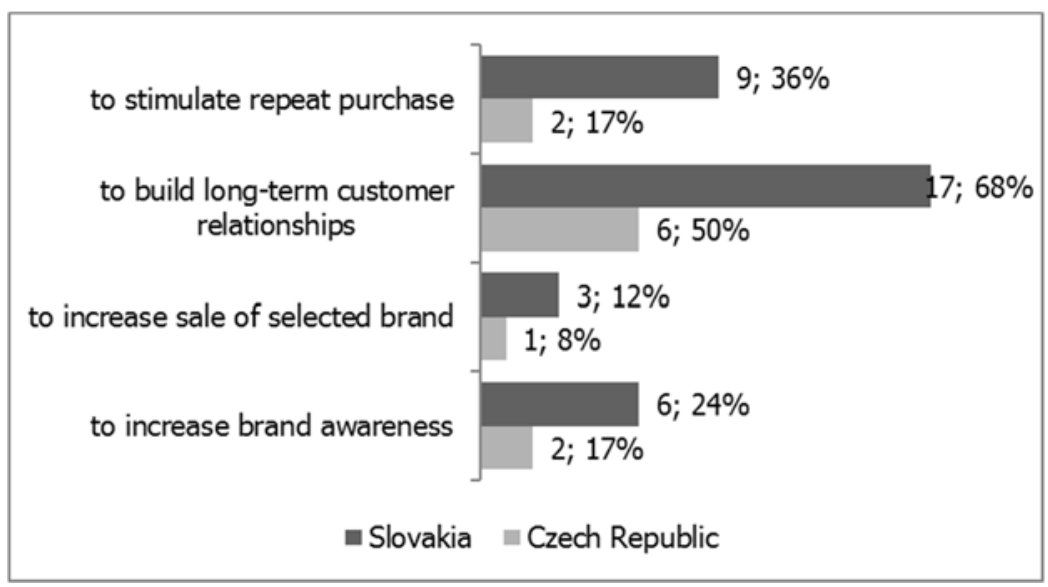

Source: own results 


\subsection{Discussion}

There are many studies dedicated to the consumers 'attitude and behavior in the field of organic food market. Based on published results we know why consumers buy organic food, whether they trust in organic food or consider the price of organic food to be adequate. However, there is a lack of research studies that would be focused on the practices of business entities, especially their using of sales promotion tools at the organic food market. Therefore, the most important benefits of the presented paper are results of conducted research and recommendations for more effective sales promotion.

Based on collecting data, their processing and evaluating we suggest recommendations for Slovak and Czech producers and retailers as follow:

- Samples and tastings - sampling has become an integral part of the sales promotion mix. Marketers commonly use product samples to stimulate consumer interest (Wadhwa et al., 2008). Based on our consumer research we can claim that Slovak and Czech consumers are very interested in this sales promotion tool. At the same time, they are very excited to try new products in this way. Samples and tastings enable to introduce new product to consumers or to reach new customers. Since only $54 \%$ of Slovak and $69 \%$ of Czech consumers have previous experience with organic food samples or tastings, producers and/or retailers should use this tool more intensively.

- Discounts and discount coupons - marketers have long realized that coupons can serve as advertisements that attract new customers and inspire gratitude and loyalty among existing ones by delivering important messages about a company. The effect has become stronger in recent years as technology has enabled businesses to personalize their coupons. If businesses realized how powerful this increased awareness can be, they would take as much care with coupons as they do with other marketing materials, striving to delight customers, not simply to close a deal (Venkatesan and Farris, 2012b). In terms of the vast majority of Slovak (79\%) and Czech consumers (83\%), business entities in these countries use discount coupons or discounts sometimes or not at all. However, the consumer interest in discounts and discount coupons is very high.

- Multi-packs - multi-pack products are way to enhance consumers' purchase weight as well as raise assortment purchase. However, it is necessary to provide consumers a viable selection of products that meet their needs at the price they are willing to pay (Davey and Florio, 2016). A multi-pack product also reduces the cost involved in the packaging of the product. Multi-packaging also helps in clearing the old stocks quickly. In case of new products, multi-packs help generate trial and familiarize consumer with a larger part of brand's range in one go. A multi-pack product also helps in retaining brand loyalty so that consumer does not switch to some other brand too easy. Moreover, products of daily use sell more when are sold as a multi-pack (Pandey, 2011). 


\section{Conclusion}

Based on the research results the aim of the presented paper was to find out current state of using consumer-oriented sales promotion tools at the organic food market and to suggest recommendations for improvement. We set two research questions: (1) Which tools use of sales promotion do business entities in the field of organic food in Slovakia and Czech Republic? (2) What is the attitude of the producers and retailers of organic food in Slovakia and Czech Republic to the selected tools of sales promotion?

In terms of Slovak and Czech business entities, we can conclude that the most used consumer-oriented sales promotion tools are information materials, merchandising and multipacks. The most implemented sales promotion tools represent non-monetary tools that do not cause any other additional costs for retailers. They are easy to use. On the other side the least used tools are games and contests; loyalty programs and gift items. Based on evaluating of the average assessment of individual tools we found out that the sales promotion tools are used just often (the average rating of all tools was higher than 3 which correspond to the frequency of often to never). The results point to insufficient implementation of sales promotion tools at the organic food market and probably low interest of business entities to them.

Furthermore, we focused also on the attitude of business entities to claims that indirectly relate to using of consumer-oriented sales promotion tools in practice. If we generalize obtained results, the Slovak business entities claim that consumers are loyal to one organic food brand and are not price sensible. At the same time, they have enough information about products they are buying. Consumers are motivated to buy a certain product by discount coupons and/or samples and tastings at the point of purchase. The results did not testify to the discounted products would be sold easier. Moreover, this part of research revealed that merchandising is important sales promotion tool not only in Slovakia, but also in the Czech Republic. Differences between these two countries are recorded in the consumer loyalty to one organic food brand. In terms of the Czech business entities, consumers are not informed about product they are buying adequately. Discount coupons and/or samples and tastings at the point of sale motivate Czech consumers to buy presented product, too.

Majority of the Slovak and Czech business entities provide discounts to increase sale of products. The main reason why they give away gift items is to build long-term customer relationships. These results reveal focus on their financial benefits of sales promotion more than on the benefits for consumers.

Finally, as we identified the lack of studies dedicated to sales promotion application by business entities at the organic food market, the most important benefits of the presented paper are results of conducted research and recommendations for more effective sales promotion. Moreover, the results of consumer research that we conducted previously confirm the results presented in this paper. As we found out (in the previous consumer research), the consumers were not faced with very encouraging sales promotion activities when buying organic food. It is confirmed by the results of this research the use of consumer-oriented sales promotion tools by producers and retailers are considered to be insufficient. 


\section{References}

Bain, M. (2013). The Psychology of Sales: Why Reciprocity Matters Retrieved March 19, 2017, from https://www.salesforce.com/blog/2013/10/sales-psychology-ofselling.html

Barański, M. et al. (2014). Higher antioxidant and lower cadmium concentrations and lower incidence of pesticide residues in organically grown crops: a systematic literature review and meta-analyses. British Journal of Nutrition, 112(5), 794-811.

Brito, P. Q., \& Hammond, K. (2007). Strategic Versus Tactical Nature of Sales Promotions. Journal of Marketing Communications, 13(2), 131-148.

Dangour, A. et al. (2009). Nutritional quality of organic foods: a systematic review. The American Journal of Clinical Nutrition, 90(3), 680-685.

Davey, K. S., \& Florio, R. (2016). Price Pack Architecture: A Proven Strategy for Sustainable and Profitable Innovation. Retrieved March 17, 2017, from https://www.iriworldwide.com/IRI/media/IRI\%20-\%20Price\%20Pack\%20Architecture\%20POV.pdf

De Pelsmacker, P., Geuens, M., \& Van Den Bergh, J. (2001). Marketing Communications. London: Prentice Hall.

Dickieson, J., \& Arkus, V. (2009). Factors that influence the purchase of organic food: A study of consumer behaviour in the UK: projekt. London: Cass Business School.

Elzakker, B., \& Eyhorn, F. (2010). Organic Business Guide. Germany : IFOAM.

Guido, G. (2009). Behind Ethical Consumption: Purchasing Motives and Marketing Strategies for Organic Food Products, Non-GMOs, Bio-Fuels. Bern: Peter Lang AG International Academic Publishers.

Guido, G. et al. (2010). The Role of Ethics and Product Personality in the Intention to Purchase Organic Food Products: A Structural Equation Modeling Approach. International Review of Economics, 571), 79-102.

Hughner, R. et al. (2007). Who are organic consumers? A compilation and review of why people purchase organic food. Journal of Consumer Behaviour. 6(2-3), 94110.

Kahl, J. et al. (2012). Organic food quality: a framework for concept, definition and evaluation from the European perspective. Journal of the Science of Food and Agriculture, 92(14), 2760-2765.

Kahl, J., Busschner, N., \& Ploeger, A. (2010). Questions on the validation of holistic methods of testing organic food quality. Biological Agriculture and Horticulture, $2 \pi(14), 81-94$.

Köksal, Y., \& Spahiu, O. (2014). The Efficiency of Monetary and Non-Monetary Sales Promotions on Brand Preference: A Case of Albanian GSM Companies. Istanbul University Journal of the School of Business, 43(2), 319-331.

Marketing-schools.org. (2016). Marketing organic products. Retrieved November 11, 2016, from http://www.marketing-schools.org/consumer-psychology/marketingorganic-products.html 
Mela, C. F., Gupta, S., \& Lehmann, D. R. (1997). The Long-term Impact of Promotion and Advertising on Consumer Brand Choice. Journal of Marketing Research, 34(2), 248-261. DOI: 10.2307/3151862.

Nagar, K. (2009). Evaluating the Effect of Consumer Sales Promotions on Brand Loyal and Brand Switching Segments. Vision: The Journal of Business Perspective, 13(4), 35-48.

Owens, D. L., Hardman, M. \& Keillor, B. (2001). The Differential Impact of Price-Related Consumer Promotions on Loyal versus Non-Loyal Users of the Brand. Journal of Promotion Management, 6(1-2), 113-131.

Pandey, R. (2011). Multi benefits with Multi-pack Retrieved September 2, 2017, from https://retail.franchiseindia.com/magazine/2011/august/Multi-benefits-with-Multipack.m49-2-2/.

Papatla, P., \& Krishnamurthi, L. (1996). Measuring the Dynamic Effects of Promotions on Brand Choice. Journal of Marketing Research, 33(1), 20-35. DOI: $10.2307 / 3152010$.

Pino, G., Peluso, A. M., \& Guido, G. (2012). Determinants of Regular and Occasional Consumers 'Intentions to Buy Organic Food. Journal of Consumer Affairs, 46(1), 157-169.

Siegrist, M. (2008). Factors Influencing Public Acceptance of Innovative Food Technologies and Products. Trends in Food Science \& Technology, 19(11), 603-608.

Srilekha, J., \& Jawahar, R. K. (2011). The Impact of Promotional Offers in off Season with Special Reference to Big Bazaar. International Journal of Current Research, 33(3), 54-59.

Venkatesan, R., \& Farris, P. W. (2012a). Measuring and Managing Returns from Retailer-Customized Coupon Campaigns. Journal of Marketing, 76(1), 76-94.

Venkatesan, R., \& Farris, P. W. (2012b). Unused Coupons Still Pay Off. Retrieved March 17, 2017, from https://hbr.org/2012/05/unused-coupons-still-pay-off.

Wadhwa, M., Shiv, B., \& Nowlis, S. M. (2008). A Bite to Whet the Reward Appetite: The Influence of Sampling on Reward-Seeking Behaviors. Journal of Marketing Research, 45(4), 403-413. 